\title{
Hypothesis:Targeted $l k k \beta$ deletion upregulates MIF signaling responsiveness and MHC class II expression in mouse hepatocytes
}

This article was published in the following Dove Press journal:

Hepatic Medicine: Evidence and Research

20 March 2010

Number of times this article has been viewed

\section{Katherine S Koch \\ Hyam L Leffert}

Hepatocyte Growth Control and Stem Cell Laboratory, Department of Pharmacology, School of Medicine, University of California, San Diego, CA, USA
Correspondence: Katherine S Koch and Hyam L Leffert

Hepatocyte Growth Control and Stem Cell Laboratory, Department of Pharmacology, School of Medicine, University of California, San Diego, 9500 Gilman Drive MC 0636, La Jolla, CA 92093-0636, USA

Tel +l 8585342354

Fax + I 8588224184

Email kskoch@ucsd.edu; hleffert@ucsd.edu
Abstract: Macrophage migration inhibitory factor (MIF) is causally related to the pathogenesis of chronic liver disease but its hepatocellular mechanisms of action are largely unknown. Scattered reports in the literature hint at functional connections between the expression of MIF and major histocompatibility complex (MHC) Class II molecules. Not surprisingly, these relationships have not yet been explored in hepatocytes because MIF and MHC Class II cell surface receptors are commonly expressed by other cell types including various antigen presenting cells of the immune system. On the other hand, mounting evidence suggests that heteromeric MIF receptors share a common molecule with intracellular MHC Class II complexes, viz., CD74, which also serves as the MHC Class II chaperone; and, while it is unclear what cancer-related role(s) MHC Class II receptors might play, increasing evidence suggests that MIF and CD74 are also implicated in the biology of hepatocellular carcinoma. These reports are provocative for two reasons: firstly, Ikk $\beta^{\Delta h e p}$ mice carrying hepatocyte-targeted deletions of $I k k \beta$, an IKB kinase complex subunit required for the activation of the transcription factor NF- $\kappa B$ (nuclear factor- $\mathrm{\kappa B}$ ), have been shown to display heightened susceptibilities to hepatotoxins and chemical hepatocarcinogens; secondly, microarray profiling observations indicate that $I k k \beta^{\Delta h e p}$ hepatocytes constitutively and "ectopically" overexpress genes, particularly CD74, CD44 (a MIF-receptor subunit) and MHC Class II I-A/E $\beta$ and I-A $\alpha$ chains, and gene families that regulate host immune process and immune defense responses. These findings together suggest that $I \mathrm{kk} \beta^{\Delta h e p}$ mice might express functional MIF and MHC Class II receptors, leading to increased hepatocellular sensitivity to MIF signaling as well as to the unusual property of antigen presentation; both functions might contribute to the heightened liver disease phenotypes of $I k k \beta^{\Delta h e p}$ mice. The findings raise questions about the potential existence of cohorts of human patients with genetic abnormalities of $I k k \beta$ that might confer heightened susceptibility to liver disease including hepatocellular carcinoma.

Keywords: hepatocellular toxicity, inflammation, immunity, carcinoma

\section{Introduction}

Liver disease is a major cause of suffering worldwide and is associated with a significant financial burden. ${ }^{1-4}$ In the US alone, based on statistics compiled in 2008, 36,000 people died from liver disease in 2004 and one of every six deaths resulted from primary hepatocellular carcinoma (HCC), one of the most aggressive malignancies known. ${ }^{4}$ The financial cost of all liver disease was US\$13 billion, almost two-thirds of which were accounted for by HCC and viral hepatitis. ${ }^{4}$ Although HCC is associated with exposure to hepatotoxic environmental carcinogens and toxins, ${ }^{5}$ with clinical disorders including autoimmune hepatitis, primary biliary cirrhosis and sclerosing cholangitis, ${ }^{6,7}$ and with a three-fold higher male gender preference, ${ }^{8}$ its major associations with viral hepatitis infection (particularly 
HBV and HCV) and chronic liver inflammation have been known for many years and widely investigated. ${ }^{9,10}$

$\mathrm{HCC}$ continues to be an intractable human health problem. It is endemic to Southeast Asia and Africa ${ }^{11}$ and its incidence is rising worldwide, particularly in the US. ${ }^{12}$ For example, in 2006, the American Cancer Society recorded HCC in roughly 18,000 American men and women, with an overall death rate of $90 \%{ }^{11,12}$ Of the 7.4 million cancer deaths worldwide, the World Health Organization ranked death rates from $\mathrm{HCC}$ as fourth (610,000 deaths) among the five most prevalent malignancies (along with lung, gastric, colorectal and breast). This ranking is $18 \%$ higher than for breast cancer $(519,000$ deaths $) .{ }^{13}$

In addition to these grim statistics, the precise molecular and cellular mechanisms that cause HCC have been difficult to identify, not only because of the complexities inherent in dissecting the initiation and progression of malignant disease, but also because of the limited development of experimental laboratory models which accurately and reliably reflect various human HCC etiologies. However, recent work at the basic science level suggests these difficulties are being addressed in meaningful ways. For example, increasing genomics analyses have identified many genetic signaling systems that govern hepatocellular carcinogenesis, and which can be corroborated in several murine model systems. ${ }^{14,15}$ In relation to these genetic findings, the mouse model of HCC induced by the procarcinogen diethylnitrosamine (DEN), has been suggested to reflect a course etiologically comparable with that of human HCC. ${ }^{15}$

\section{Ikk $\boldsymbol{\beta}^{\Delta \text { hep }}$ mice: A model system for studies of augmented susceptibility to hepatotoxicity, DEN induction of HCC and hepatocyte growth advantages}

One promising mouse model system, notable for its concomitant use of related but distinct gene-targeted strains to reveal intrahepatic cell-cell interactions involved in DEN-induced hepatocarcinogenesis, has focused on the $I k k \beta$ gene. ${ }^{16} I k k \beta$ encodes an $87 \mathrm{kDa}$ protein kinase subunit (IKK $\beta$ ) of the I $\mathrm{KB}$ complex (IKK). ${ }^{17}$ As an IKK member, IKK $\beta$ is ubiquitously required for activation of nuclear factor- $\kappa \mathrm{B}(\mathrm{NF}-\kappa \mathrm{B}),{ }^{17,18}$ a multifunctional transcription factor that governs innate and adaptive immunity, cell survival and cellular susceptibility to carcinogenesis. ${ }^{19,20}$ However, IKK $\beta$ also has other signaling roles in many different types of cells. ${ }^{17-21}$

Parallel in vivo and in vitro investigations have led to the hypothesis that hepatic IKK $\beta$ has a bifunctional role as an hepatocellular growth and tumor suppressor, ${ }^{16,21}$ and as an NF- $\kappa \mathrm{B}$-dependent regulator of liver nonparenchymal cell (NPC) cytokine secretion. ${ }^{16,21-23}$ Paradoxical aspects of this hypothesis have been supported by experiments with two different strains of conditional knockout mice. Both strains are on a C57BL/6Ikk $\beta^{F / F}$ background, in which the $I k k \beta$ exon 3 and most of the kinase domain are flanked by Cre-recombinase lox sites, the span of which is targeted for deletion by the specific promoter-driven expression of Cre-recombinase. The Alb-Cre-driven strain, in which augmentation of DEN-induced HCC formation occurs, is characterized by $I k k \beta^{\lrcorner}$in hepatocytes alone (Ikk $\beta^{\text {shep }}$ mice), because deletion is targeted by an albumin promoter which controls Cre-recombinase expression. In the sister strain, Mx1-Cre, in which DEN-induced HCC formation is attenuated, the Mx1-Cre promoter, in response to poly(IC) treatment, drives expression of Cre-recombinase to delete $I k k \beta$ in hepatocytes as well as in intra- and extrahepatic myeloid cells (Ikk $\beta^{\Delta L+H}\left[I k k \beta^{\Delta L I V}\right]$ mice).$^{16}$

Initial findings with $I k k \beta^{\text {shep }}$ mice indicated that, compared with control $I k k \beta^{F / F}$ mice, hepatotoxicity was augmented significantly by treatments with Con-A or LPS/galactosamine. ${ }^{24}$ Augmented toxicities in Ikk $\beta^{\text {shep }}$ mice, attributed to requirements for IKK $\beta$ for the prevention of hepatocyte apoptosis, were mediated by T-cell bound TNF $\alpha$ activation of hepatocyte TNF $\alpha$-receptor 2, with subsequent reactive oxygen species (ROS) formation, leading to the inhibition of mitogen-activated protein kinase (MAPK) phosphatases, and thus resulting in sustained JNK1 activation. ${ }^{25}$ Working with $I k k 2^{\Delta h e p a}$ mice deleted in $I k k \beta$ exons 6-7 on a different strain background, ${ }^{26,27}$ others subsequently reported that $I k k \beta^{\lrcorner}$did not sensitize TNF $\alpha$-induced hepatocyte apoptosis; ${ }^{26}$ rather, hepatocyte survival in $I k k 2^{\Delta h e p a}$ mice depended upon IKK $\alpha / \gamma$ subunits. ${ }^{28}$ These differences remain unclarified ${ }^{29}$ but might reflect different TNF $\alpha$ injection protocols; alternatively, delayed S-phase peaks after 70\% partial hepatectomy $(\mathrm{PH})^{27,30}$ might also suggest that $I k k 2^{\Delta h e p a}$ mice are differentially affected by exon 6-7 targeting.

Subsequent HCC-induction studies using both $I k k \beta^{\text {shep }}$ and $I k k \beta^{\lrcorner L I V}$ strains showed that, compared with $I k k \beta^{F / F}$ mice, several DEN-dependent events were augmented in $I k k \beta^{\text {shep }}$ mice: ROS formation, hepatocyte apoptosis and necrosis; prolonged activation of hepatic $c$-jun nuclear kinase 1 (JNK1); release of signaling and growth regulatory molecules from hepatocytes and liver NPCs, respectively; compensatory hepatocyte proliferation (CHP); and, eventual multinodular HCCs presumably derived from $I k k \beta^{\Delta}$ hepatocytes. ${ }^{16}$ Further studies with DEN indicated that IL-1 $\alpha$, an "alarmin" released 
from necrotic hepatocytes, stimulated Kupffer cells (KCs) to secrete IL-6, which, in turn, augmented JNK1 activation, proliferation of DEN-initiated $I k k \beta^{\text {shep }}$ hepatocyte survivors and subsequent progression to HCC.22 These observations positioned augmented ROS formation and hepatocyte death as major determinants of augmented $\mathrm{HCC}$ during hepatocarcinogenesis in $I k k \beta^{\text {\hep }}$ mice.

However, it was also reported that, compared with $I k k \beta^{F / F}$ hepatocytes, Ikk $\beta^{\text {shep }}$ hepatocytes in primary culture showed cell-autonomous growth advantages including enhanced recovery efficiency, precocious cyclin D1 expression, elevated S-phase BrdU-labeling indices (LIs), and enhanced growth-factor sensitivity to hepatocyte mitogens like TGF $\alpha$ and TNF $\alpha .^{21}$ The same study showed that, compared with $I k k \beta^{F / F}$ hepatocytes, Ikk $\beta^{\text {shep }}$ hepatocytes also displayed in vivo growth advantages during liver regeneration following $70 \% \mathrm{PH}$; these consisted of precocious elevations in PCNA, cyclin D1 and S-phase LIs (ie, shortened $\mathrm{G}_{0} \rightarrow \mathrm{G}_{1}$ transitions), and elevated numbers of mitotic figures. Most recently, a series of syngeneic transplantation and pharmacologic studies $^{31}$ has suggested that the augmented intrinsic capacity of cell-autonomous proliferation reflected in hepatocyte proliferative advantages conferred by $I k k \beta$ deletion ${ }^{21}$ or $I k k \beta$ inhibition, or the proliferative disadvantages conferred by IKK $\beta$ overexpression, are also determinants of HCC promotion and progression in $I k k \beta^{\Delta}$ and $I k k \beta^{+}$mice..$^{21,31}$

This conclusion is consistent with the well established fact that chemical hepatocarcinogenesis requires cell proliferation during the phase of tumor "initiation", when cell selection generates survivors that propagate carcinogen-induced growthaltering mutations, and during the phases of tumor promotion and progression, which allow further proliferative expansion and evolution of tumor cell populations that have escaped normal growth controls. Current hypotheses emphasize ROS formation and cell death as major causes of $\mathrm{KC}$ activation and CHP, rather than intrinsic growth advantages of $I k k \beta^{\text {shep }}$ hepatocytes, both because both former processes were inhibited by the anti-oxidant butylated hydroxyanisole (BHA) when administered over consecutive two-day intervals, before and after HCC-initiation by DEN, and because selective depletion of $\mathrm{KCs}$ by $\mathrm{GdCl}_{3}$ injections 24 hours prior to DEN treatment reduced subsequently elevated $\mathrm{CHP}$, as well as $\mathrm{KC}$-generated increases of TNF $\alpha$, IL-6 and HGF mRNAs. ${ }^{16,22}$

While there is little doubt that ROS formation and ROSmediated $\mathrm{KC}$ activation are etiologically involved in DENinduced $\mathrm{HCC}$, as proposed from observations with this $I k k \beta$ deletion model, ${ }^{16,22,23,25}$ and from findings in mice specifically ablated in hepatocyte NEMO/IKK $\gamma$ regulatory subunits of
IKK, that develop spontaneous $\mathrm{HCC},{ }^{32}$ it has also been shown that (a) BHA concomitantly blocked many cellular processes in standard DEN-induction models; ${ }^{16,22}$ and that, (b) liver repletion of $\mathrm{KCs}$ occurs shortly after $\mathrm{GdCl}_{3}$ treatment. ${ }^{33}$ Thus, along with BHA inhibition of ROS formation, hepatocyte necrosis and apoptosis, reduction by BHA of serum ALT levels, and the ability of BHA to blunt significantly hepatocyte DNA-adduct formation, ${ }^{34}$ BHA treatment almost completely inhibited DEN-induced hepatocyte proliferation, in a quantitatively greater percentage than its inhibitory effects on HCC tumor number and tumor size..$^{16,22}$

Consequently, to understand more fully the major causes of augmented HCC formation in $I k k \beta^{\text {shep }}$ mice, consideration is given here to other underlying causes of hepatocellular growth advantage, and to other potential cytokine-dependent mechanisms of macrophage activation (e.g., interferon $\gamma[$ IFN- $\gamma]) .{ }^{35}$ Here we propose new research directions to identify other contributing, but perhaps fundamental, mechanisms of DEN-induced HCC in Ikk $\beta^{\text {shep }}$ mice.

One direction might focus on genetic and biochemical investigations of potential intergenotypic differences in the formation, types and stability of hepatocyte DNA-adducts in DEN-treated $I k k \beta^{F / F}$ and $I k k \beta^{\text {shep }}$ mice. Thus far, however, quantitative differences in DNA-adduct formation have not been detected between the two genotypes. ${ }^{16}$ Another might explore the possible selection by DEN for the emergence of premalignant liver stem or liver cancer stem cells ${ }^{36-38}$ in $I k k \beta^{\text {shep }}$ mice. However, apart from critical experimental issues surrounding the identification of such stem cells, as well as the necessity to combine studies of fate-mapping, fluctuation analysis, cell-cell fusion and systematic dilution of transplanted cells ${ }^{38}$ it should be noted that past and current evidence ${ }^{14-16,35,38}$ suggests that mature $I k k \beta^{4}$ hepatocytes are HCC-progenitors in both models of DEN-induced HCC.

\section{New hypothesis and research directions concerning HCC etiology: Preliminary evidence and general background}

Recent observations from our laboratory have revealed unusual and unexpected constitutive phenotypes of hepatocytes in $I k k \beta^{\text {shep }}$ mice..$^{39}$ Comparative microarray profiling studies suggest that, in comparison with $I k k \beta^{F F}$ hepatocytes, $I k k \beta^{\text {thep }}$ hepatocytes express very high mRNA levels of CD74 (the MHC class II chaperone) $)^{40}$ and MHC class II I-A/E $\beta$ and I-A $\alpha$ chains; significant overexpression of genes encoding large families of molecules involved in innate and adaptive 
immunity, including CD44, CIITA, signal transducer and activator of transcription (STAT) 1, cathepsin S and coactivator $\mathrm{CD} 86$, as well as IFN- $\gamma$ regulation have also been observed. Examples of high scoring results are shown in Table 1. Western blot and immunohistochemical findings support observations of $I k k \beta^{\text {shep }}$ hepatocyte-restricted expression of CD74 and MHC Class II molecules (unpublished observations).

Based upon these observations, we propose the hypothesis that augmented susceptibility of $I k k \beta^{\text {shep }}$ mice to $\mathrm{HCC}$ requires functional hepatocellular expression of CD74, MIF ${ }^{41,42}$ receptors, IFN- $\gamma$ regulatory proteins, and antigen-presentation by $\mathrm{MHC}$ class II receptors. We refer to this apparently unique phenotypic cluster as "hepatic

Table I Overexpression of key genes in $I k k \beta^{\Delta \text { thep }}$ hepatocytes revealed by microarray profiling

\begin{tabular}{|c|c|}
\hline Description & $\mathbf{E}^{\mathrm{a} / \mathbf{R}^{\mathrm{b}}}$ \\
\hline \multicolumn{2}{|l|}{ Defense response $P<1.4^{-21}$} \\
\hline CD74 antigen (invariant polypeptide) & $38.3 / 4.6$ \\
\hline Interferon gamma inducible protein 47 (Ifi47) & $7.2 / 3.2$ \\
\hline Immunity-related GTPase family, M (Irgm) & $6.5 / 3.7$ \\
\hline TAP binding protein (Tapbp) & $5.2 / 2.3$ \\
\hline CD44 antigen (Cd44) & $4.3 / 1.9$ \\
\hline Histocompatibility 2,T region locus 10 (H2-TI0) & $4.2 / 3.2$ \\
\hline Transporter I, ATP-binding (MDR/TAP) (TapI) & $4 / 1.9$ \\
\hline Toll-like receptor 2 (TIr2) & $4 / 1.7$ \\
\hline Complement component I, ( $\mathrm{Clqb})$ & $4 / 1.4$ \\
\hline Chemokine ( $\mathrm{C}-\mathrm{C}$ motif) receptor 5 ( $\mathrm{Ccr} 5)$ & $3.9 / 2.1$ \\
\hline Lysozyme (Lyz) & $3.9 / 1.7$ \\
\hline \multicolumn{2}{|l|}{ Immune system process $P<1.2^{-18}$} \\
\hline Histocompatibility 2, class II antigen A, beta I & $22.5 / 2.5$ \\
\hline Histocompatibility 2, class II antigen E beta & $\mid 8.2 / 2.1$ \\
\hline Histocompatibility 2, class II, locus DMa (H2-DMa) & $|5.8 / 3|$. \\
\hline Histocompatibility 2, class II antigen A, alpha & $14.4 / 2.3$ \\
\hline T-cell specific GTPase (Tgtp) & $13.3 / 4.8$ \\
\hline Guanylate nucleotide binding protein I (Gbpl) & $11.9 / 4.3$ \\
\hline Histocompatibility 2, class II, locus MbI (H2-DMbI) & $10.6 / 3.2$ \\
\hline Histocompatibility 2, class II, locus Mb2 (H2-DMb2) & $9.4 / 2.8$ \\
\hline Guanylate nucleotide binding protein 3 (Gbp3) & $9 / 3.9$ \\
\hline Guanylate nucleotide binding protein 2 (Gbp2) & $7 / 2.9$ \\
\hline Chemokine (C-X-C motif) ligand 9 (Cxcl9) & $6.5 / 1.3$ \\
\hline CD274 antigen (Cd274) & $5.5 / 2.9$ \\
\hline Proteasome (prosome, macropain) (Psmb9) & $5.3 / 1.6$ \\
\hline Interferon regulatory factor I (IrfI) & $4.2 / 2.1$ \\
\hline
\end{tabular}

Notes: ${ }^{\mathrm{a}} \mathrm{E}=\mathrm{X}$-fold higher expression $\left(\mathrm{lkk} \beta^{\text {thep }}>\mathrm{Ikk} \beta^{\mathrm{F} / \mathrm{F}}\right)$; and, ${ }^{\mathrm{b}} \mathrm{R}=$ ratio of expression ([isolated hepatocytes]/[whole liver tissue]). See Koch and Leffert ${ }^{39}$ for details of microarray profiling. immunologic ectopia" (see Figure 1). One or more of these functions, if activated, might lead to hepatocellular antigen presentation, proliferation and/or death (via apoptosis or necrosis). Various MAPK and STAT pathways may be called into play as mediators of these responses.

An extensive experimental and clinical literature lends support to several aspects of this hypothesis. CD74 is a key mediator of the toxic and proinflammatory effects of MIF. ${ }^{41-43}$ The $9.2-\mathrm{kb}$ mouse CD74 gene resides on chromosome 18; it consists of nine exons which generate six mRNA splice variants by alternative splicing. ${ }^{40}$ Two CD74 isoforms, polypeptides of $31 \mathrm{kDa}$ and $41 \mathrm{kDa}$ (which contain chondroitin sulfate side chains), generate Type II membrane glycoproteins with 30 amino acid cytoplasmic tails. ${ }^{40,41,44}$ CD74 is widely expressed by B-cells, monocytes, and macrophages ${ }^{41-43}$ including hepatic stellate cells (HSCs); ${ }^{45}$ a rare and sparse periportal subpopulation of $\mathrm{CD} 74^{+}$hepatocytes has been reported in wild-type B10.BR mice. ${ }^{46}$ Notably, CD74 is associated with two reported biochemical mechanisms unrelated to its intracellular chaperone function (Figure 1). Firstly, in DNA-mediated transfection studies with human 293 cells, regulated intracellular proteolysis (RIP) of CD74 releases a $10 \mathrm{kDa}$ cytoplasmic fragment that migrates into the nucleus where it activates p65 and NF- $\kappa \mathrm{B} .{ }^{47}$ And, secondly, although MIF has also been reported to be a noncognate ligand of $\mathrm{CXCR} 2$ and $\mathrm{CXCR} 4$ chemokine receptors in monocytes and T cells, ${ }^{48}$ perhaps of more relevance to our hypothesis are plasma membrane complexes of CD74/CD44 which have been shown to mediate MIF signaling in most cell systems studied thus far (viz., CD74/CD44 complexes are considered to be the major MIF receptor acting via one or more MAPK pathways). ${ }^{49-52}$

MIF, a $12.5 \mathrm{kDa}$ proinflammatory cytokine, is associated with multisystemic disease..$^{49,53}$ MIF is secreted as a soluble homotrimer from preformed pools by T-, B- and epithelial cells, ${ }^{41-43,54}$ as well as by liver $\mathrm{KCs},{ }^{55}$ in response to toxins, endotoxins, and cytokines including Con-A, LPS, TNF $\alpha$ and IFN- $\gamma \cdot{ }^{56-59}$ MIF expresses intrinsic enzymatic activities, and it induces cyclin D1, mitogenesis and nitric oxide production..$^{42,53,60}$ MIF is causally related to the pathogenesis of chronic liver disease, ${ }^{61} \mathrm{HBV}$ infection ${ }^{62}$ and acute liver failure following alcoholic hepatitis, ${ }^{63,64}$ it is found in hepatocytes from fibrotic livers of thioacetamide- and ConA-treated mice, ${ }^{65,66}$ and it is causally involved in Bacille-CalmetteGuerin-primed LPS-induced T-cell-mediated acute liver failure (BLTLF). ${ }^{55}$ Of potential clinical importance, anti-MIF Abs and MIF anti-sense cDNA block BLTLF and LPSinduced liver injury, respectively; ${ }^{55,67}$ anti-MIF antibodies 


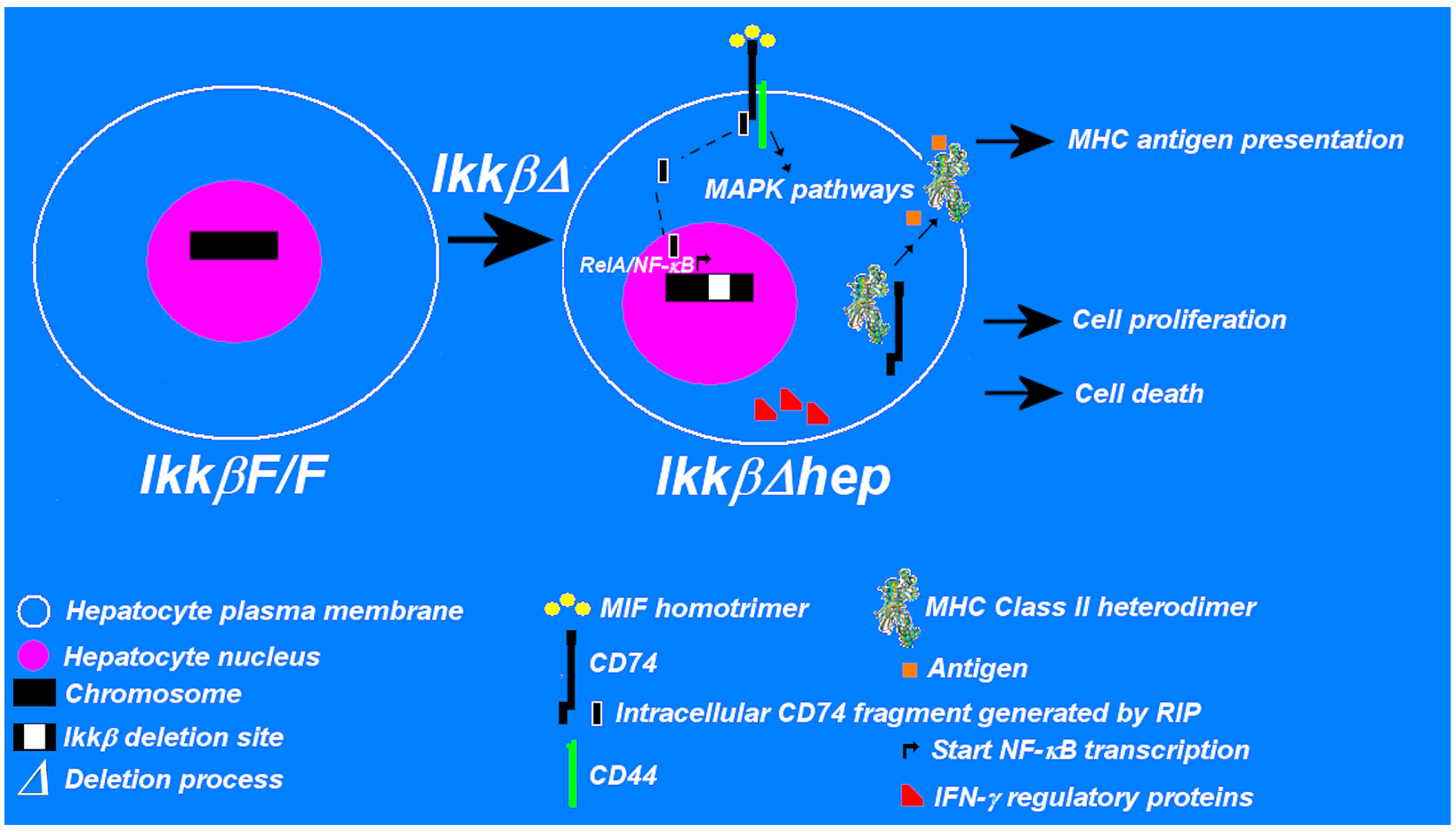

Figure I Hepatic immunologic ectopia: a constellation of constitutive immunophenotypes associated with lkk $\beta^{\text {thep }}$ hepatocytes. The diagram illustrates elements of the basic hypothesis, viz., that compared to $I k k \beta^{f / F}$ hepatocytes, Ikk $\beta^{\text {shep }}$ hepatocytes ectopically express MIF receptors associated with MAPK signaling pathways, IFN- $\gamma$ regulatory proteins which facilitate hepatocellular responses to IFN- $\gamma$ (an activator of hepatic macrophages, as well as several immune system cells that may be situated in hepatotoxic livers), and antigen-presentation-competent MHC class II receptors (which respond to DEN-associated antigens and elicit specialized intrahepatic CD4 ${ }^{+}$and $\mathrm{CD} 8^{+} \mathrm{T}$ cell responses). CD74 serves a triple role: as a component of the MIF receptor along with CD44 (at plasma membrane sites); as a source of RIP-mediated fragments that migrate into the nucleus where they activate $\mathrm{p} 65$ ('RelA')/NF- $\mathrm{KB}$-mediated transcription; and, as the intracytoplasmic MHC Class II chaperone in a complex with MHC Class II heterodimers that binds processed antigen (the antigen is then presented extracellularly). Depending upon the intrahepatic microenvironment, the separate or collective functions of these molecules are postulated to lead to cellular immune system-mediated anti-hepatocyte responses, hepatocyte proliferation and/or hepatocyte death. The annotations and symbols are defined in the figure (see text and references for further details).

Abbreviations: MAPK, mitogen-activated protein kinase; MHC, major histocompatibility complex; MIF, macrophage migration inhibitory factor; RIP, regulated intramembrane proteolysis.

also attenuate experimentally-induced murine colitis $;^{57}$ MIF-knockout mice are also protected from LPS- ${ }^{68}$ ConA- ${ }^{66}$ and acetaminophen-mediated ${ }^{69}$ liver injuries. And surprisingly, as mentioned above, in comparison with expression in $I k k \beta^{F / F}$ hepatocytes, numerous immune process and host defense genes are highly and constitutively overexpressed in $I k k \beta^{\text {shep }}$ hepatocytes-phenotypes that, along with growth advantages, might also augment Ikk $\beta^{\text {shep }}$ susceptibility to MIF and HCC.

CD74 and MIF are also implicated in the biology of human HCC. A role for MIF was first suggested when transplanted hepatoma ascites cell lines, obtained from DEN-treated guinea pigs, were rejected by what appeared to be adherent intraperitoneal macrophage aggregates. ${ }^{70}$ Subsequent reports showed that MIF and CD74 expression were altered or heightened in many malignancies including HCC. ${ }^{61,71-78}$ CD74 is a gastric epithelium receptor for Helicobacter pylori, the major cause of gastric ulceration and gastric carcinoma; ${ }^{72,73}$ notably, $H$. pylori reportedly affects the growth and death of infected human hepatocytes. ${ }^{79,80}$ In HCC, elevated MIF expression is correlated with augmented cyclin D1 expression (a hallmark of activated hepatocyte proliferation, ${ }^{81}$ tumor size and metastasis, ${ }^{82}$ and tumor angiogenesis), ${ }^{83,84}$ whereas reduced MIF expression upregulates the cell-cycle CDK inhibitor, p27. ${ }^{85}$ Serum levels of MIF are high in cirrhotic patients with HCC. ${ }^{61,62,71}$ MIF is directly mitogenic in several systems ${ }^{51,52,60}$ including human HepG2 cells. ${ }^{86,87}$ Circulating levels of MIF increase following human liver resection, ${ }^{88}$ and if secreted, might explain reduced intrahepatic levels of MIF after 70\% $\mathrm{PH} .{ }^{89}$ Microarray profiling suggests complex associations between hepatic $\mathrm{CD} 74$ expression and the intrahepatic recurrence of human $\mathrm{HCC}{ }^{76}$

In a provocative study designed to investigate the roles of IFN- $\gamma$ (a macrophage activator produced by NK, NKT and dendritic cells, and by $\mathrm{CD} 4^{+} \mathrm{Th} 1-$ and $\mathrm{CD} 8^{+} \mathrm{T}-$-cells $)^{90}$ and of IFN- $\alpha / \beta$ as mediators of DEN-induced HCC, quantitative measurements of intrahepatic cytokine mRNA expression in adult $129 \mathrm{SV}$ mice, chronically fed DEN in their drinking water, indicated that, compared with levels in vehicle-fed wild-type mice, MIF (which was elevated at 1 month, and 
peaked at 3 months along with HCC infiltrating monocytes and macrophages), IFN- $\gamma$ and IFN- $\beta$ (which peaked at 4-5 months), and TNF $\alpha$ (which peaked at 3-4 months) were all induced by DEN treatment, concomitantly with HCC onset at 2-3 months; HCC incidence reached 100\% between 4-5 months. ${ }^{35}$ In contrast, although tumor diameters did not differ among groups, the numbers of DEN-induced $\mathrm{HCCs} /$ liver in IFN- $\gamma$-receptor knockout (IFN- $\gamma \mathrm{R}$ KO) mice fell by $60 \%$ compared with DEN-induced IFN- $\alpha / \beta R$ KO and wild-type mice. Immunohistochemical studies showed that the numbers of infiltrating mononuclear cells were greatly reduced only in the livers of IFN- $\gamma \mathrm{R} \mathrm{KO}$ mice, consistent with the observations that, in comparison with that in wild type controls, HCC-induced intrahepatic cytokine expression and oxidative DNA damage were also diminished in the IFN- $\gamma$ R KO mice. ${ }^{35}$ Although the chronic DEN feeding regimen, strain background, and $\mathrm{G}_{0}$-hepatocyte status differ from the single injection standard models in which either neonatal host or donor hepatocyte proliferation occur actively on C57BL/ 6 backgrounds, ${ }^{16,31}$ the findings with the chronic feeding regimen model strongly suggest that DEN might also induce similar cytokine expression phenotypes in standard models of DEN-induced HCC.

Lastly, ectopic MHC class II expression and competent antigen presentation, as shown by the MHC-dependent induction of proliferation of $\mathrm{CD}^{+} \mathrm{Th} 1$ and $\mathrm{CD}^{+} \mathrm{T}$ cells (the peptide-free MHC class II molecular structure shown in Figure 1 is taken from reference 91), have been observed in human HCC cell lines ( \pm IFN- $\gamma$ treatment $)^{92}$ and in antigenpresentation competent hepatocytes from CIITA-transgenic mice, the livers of which did not show constitutive autoimmunity. ${ }^{93}$ These findings, plus a report of DEN suppression of humoral immunity in adult mice, ${ }^{94}$ and our preliminary results, further raise the intriguing possibilities that innate and adaptive immune responses may preferentially occur and also affect HCC formation and fate in DEN-treated Ikk $\beta^{\text {shep }}$ mice.

\section{Conclusions and clinical implications}

New findings in $I k k \beta^{\text {shep }}$ hepatocytes are provocative because CD74, CD44 and MHC Class II molecules, which hepatocytes do not usually express, have all been linked, along with heightened MIF responsiveness, to precancerous and malignant HCC. Thus, new investigations in $I k k \beta^{\text {shep }}$ mice may well supply new explanations of enhanced human susceptibility to HCC. If obtained, such direct evidence may provide rational frameworks for translational therapies to develop novel clinical and pharmacologic interventions to prevent or attenuate the morbidity and mortality associated with human HCC.

For example, anthracycline derivatives such as epirubicin, ${ }^{95}$ daunorubicin ${ }^{96}$ and adriamycin ${ }^{97}$ are considered to be some of the most potent chemotherapeutic drugs used to treat inoperable human HCC. Not unexpectedly, one of the greatest problems with chemotherapy involves the nonspecific and toxic side effects of the administered drugs. Targeted drug delivery is therefore a major rational goal of chemotherapy of human HCC. ${ }^{98}$ The availability of transplantable primary HCC tissues or HCC cell lines, derived from human or murine biopsies of $I k k \beta^{\text {shep }}$ tumors that express cell surface CD74, would provide in vivo and in vitro model systems to evaluate the targeted effects of anti-CD74 antibodies conjugated to anthracycline derivatives. Such conjugates exist, and have already been reported to cure human B-cell lymphoma xenografts in SCID mice. ${ }^{99}$ Thus, based on the preliminary observations we have made in model system studies with $I k k \beta^{\text {\hep }}$ mice, the hypothesis advanced here might provide a rationale for new experimental HCC treatment paradigms with translational potential for treatment of human HCC, particularly should cohorts of human patients exist with genetic abnormalities of $I k k \beta$ that confer hepatic immunologic ectopia and heightened susceptibility to liver disease including HCC.

\section{Acknowledgments}

This publication was made possible by grants from the National Institute of Allergy and Infectious Diseases (R21AI067354), the National Cancer Institute (R01CA113602) and the National Institute of Environmental Health Sciences (P42ES010337).

\section{Disclosures}

The authors report no conflicts of interest in this work.

\section{References}

1. Ray KW. Global epidemiology and burden of hepatitis C. Microbes Infect. 2002;4:1219-1225.

2. Lavanchy D. Worldwide epidemiology of HBV infection, disease burden, and vaccine prevention. J Clin Virol. 2005;34 Suppl 1:S1-S3.

3. Mandeville KL, Krabshuis J, Ladep NG, Mulder CJ, Quigley EM, Khan SA. Gastroenterology in developing countries: issues and advances. World J Gastroenterol. 2009;15:2839-2854.

4. Ruhl CE, Sayer B, Byrd-Holt DD, Brown DM. Costs of digestive diseases. In: Everhart JE, editor. The burden of digestive diseases in the United States. US Department of Health and Human Services, Public Health Service, National Institutes of Health, National Institute of Diabetes and Digestive and Kidney Diseases. Washington, DC: US Government Printing Office, 2008; NIH Publication No. 09-6443, p. $137-147$. 
5. Wogan GN, Hecht SS, Felton JS, Conney AH, Loeb LA. Environmental and chemical carcinogenesis. Semin Cancer Biol. 2004;14:473-486.

6. Watanabe T, Soga K, Hirono H, et al. Features of hepatocellular carcinoma in cases with autoimmune hepatitis and primary biliary cirrhosis. World J Gastroenterol. 2009;15:231-239.

7. Nishiyama R, Kanai T, Abe J, et al. Hepatocellular carcinoma associated with autoimmune hepatitis. J Hepatobiliary Pancreat Surg. 2004; 11:215-219.

8. National Cancer Institute. SEER (incidence, mortality, gender). Available from: http://seer.cancer.gov/statfacts/html/livibd.html. Accessed on November 10, 2009.

9. Nakamoto Y, Guidotti LG, Kuhlen CV, Fowler P, Chisari FV. Immune pathogenesis of hepatocellular carcinoma. J Exp Med. 1998;188: $341-350$

10. Guidotti LG, Chisari FV. Immunobiology and pathogenesis of viral hepatitis. Ann Rev Pathol. 2006;1:23-61.

11. Garcia M, Jemal A, Ward EM, et al. Global Cancer Facts and Figures. 2007. Available from: http://www.cancer.org/docroot/STT/content/ STT_1x_Global_Cancer_Facts_and_Figures_2007.asp. Accessed on November 10, 2009.

12. El-Serag HB, Mason AC. Rising incidence of hepatocellular carcinoma in the United States. N Engl J Med. 1999;340:745-750.

13. World Health Organization. Cancer. Available from: http://www.who.int/ mediacentre/factsheets/fs297/en/ Accessed on November 10, 2009.

14. Thorgeirsson SS, Lee JS, Grisham JW. Functional genomics of hepatocellular carcinoma. Hepatology. 2006;43:S145-S150.

15. Lee JS, Thorgeirsson SS. Comparative and integrative functional genomics of HCC. Oncogene. 2006;25:3801-3809.

16. Maeda S, Kamata H, Luo JL, Leffert H, Karin M. IKK $\beta$ couples hepatocyte death to cytokine-driven compensatory proliferation that promotes chemical hepatocarcinogenesis. Cell. 2005;121: 977-990.

17. Ghosh S, Karin M. Missing pieces in the NF-אB puzzle. Cell. 2002;109: S81-S96.

18. Heyninck K, Wullaert A, Beyaert R. Nuclear factor- $\kappa B$ plays a central role in tumour necrosis factor mediated liver disease. Biochem Pharmacol. 2003;66:1409-1415.

19. Sun B, Karin M. NF-kappaB signaling, liver disease and hepatoprotective agents. Oncogene. 2008;27:6228-6244.

20. Vallabhapurapu S, Karin M. Regulation and function of NF-kappaB transcription factors in the immune system. Ann Rev Immunol. 2009; 27:693-733.

21. Koch KS, Maeda S, He G, Karin M, Leffert HL. Targeted deletion of hepatocyte $I k k \beta$ confers growth advantages. Biochem Biophys Res Commun. 2009;380:349-354.

22. Sakurai T, He G, Matsuzawa A, et al. Hepatocyte necrosis induced by oxidative stress and IL- $1 \alpha$ release mediate carcinogen-induced compensatory proliferation and liver tumorigenesis. Cancer Cell. 2008;14:156-165.

23. Naugler WE, Sakurai T, Kim S, et al. Gender disparity in liver cancer due to sex differences in MyD88-dependent IL-6 production. Science. 2007;317:121-124.

24. Maeda S, Chang L, Li ZW, Luo JL, Leffert H, Karin M. IKK $\beta$ is required for prevention of apoptosis mediated by cell-bound but not by circulating TNFo. Immunity. 2003;19:725-737.

25. Kamata H, Honda S, Maeda S, Chang L, Hirata H, Karin M. Reactive oxygen species promote TNF-alpha-induced death and sustained JNK activation by inhibiting MAP kinase phosphatases. Cell. 2005;120 649-661

26. Luedde T, Assmus U, Wüstefeld T, et al. Deletion of IKK2 in hepatocytes does not sensitize these cells to TNF-induced apoptosis but protects from ischemia/reperfusion injury. $J$ Clin Invest. 2005;115: 849-859.

27. Malato Y, Sander LE, Liedtke C, et al. Hepatocyte-specific inhibitorof-kappaB-kinase deletion triggers the innate immune response and promotes earlier cell proliferation during liver regeneration. Hepatology. 2008;47:2036-2050.
28. Luedde T, Heinrichsdorff J, de Lorenzi R, De Vos R, Roskams T, Pasparakis M. IKK1 and IKK2 cooperate to maintain bile duct integrity in the liver. Proc Natl Acad Sci U S A. 2008;105:9733-9738.

29. Leffert H, Maeda S, Karin M. Letter to Editor. August 24, 2005; Luedde T, Pasparakis M, Trautwein Letter to Editor: Response. September 6, 2005. J Clin Investig. Available from: http://www.jci.org/eletters/ view/23493 Accessed on February 14, 2010.

30. Sakamoto T, Liu Z, Murase N, et al. Mitosis and apoptosis in the liver of interleukin-6-deficient mice after partial hepatectomy. Hepatology. 1999;29:403-411.

31. He G, Yu G-Y, Temkin V, et al. Hepatocyte IKK $\beta / N F-\kappa B$ inhibits tumor promotion and progression by preventing oxidative stress driven STAT3 activation. Cancer Cell, 2010; In press.

32. Luedde T, Beraza N, Kotsikoris V, et al. Deletion of NEMO/IKKgamma in liver parenchymal cells causes steatohepatitis and hepatocellular carcinoma. Cancer Cell. 2007;11:119-132.

33. Pagliara P, Carlà EC, Caforio S, et al. Kupffer cells promote lead nitrateinduced hepatocyte apoptosis via oxidative stress. Comp Hepatol. $2003 ; 2: 8$.

34. Izzotti A, Camoirano A, Cartiglia C, et al. Patterns of DNA adduct formation in liver and mammary epithelial cells of rats treated with 7,12-dimethylbenz(a)anthracene, and selective effects of chemopreventive agents. Cancer Res. 1999;59:4285-4290.

35. Matsuda M, Nakamoto Y, Suzuki S, Kurata T, Kaneko S. Interferongamma-mediated hepatocarcinogenesis in mice treated with diethylnitrosamine. Lab Invest. 2005;85:655-663.

36. Sell S, Leffert HL. An evaluation of cellular lineages in the pathogenesis of experimental hepatocellular carcinoma. Hepatology. 1982;2:77-86.

37. Koch KS, Leffert HL. Normal liver progenitor cells in culture. In: Sell S, editor. Stem Cells Handbook, Humana Press, Inc., Totowa, NJ, 2004. p. 367-384.

38. Sell S, Leffert HL. Liver Cancer Stem Cells. J Clin Oncol. 2008; 26:2800-2805.

39. Koch KS, Leffert HL. RNA microarray profiling: Comparisons between liver tissues and freshly isolated hepatocytes from $I k k \beta \mathrm{F} / \mathrm{F}$ and $I k k \beta$ Dhep (Ikk $\beta$-deleted) mice. NCBI GEO Repository. 2009; GSE15476. Available from: http://www.ncbi.nlm.nih.gov/projects/ geo/query/acc.cgi. Accessed on November 10, 2009.

40. Bertolino P, Rabourdin-Combe C. The MHC class II-associated invariant chain: a molecule with multiple roles in MHC class II biosynthesis and antigen presentation to CD4+ T cells. Crit Rev Immunol. 1996;16:359-379.

41. Calandra T, Roger T. Macrophage migration inhibitory factor: a regulator of innate immunity. Nature Reviews Immunology. 2003;3: 791-800.

42. Leng L, Bucala R. Insight into the biology of macrophage migration inhibitory factor (MIF) revealed by the cloning of its cell surface receptor. Cell Res. 2006;16:162-168.

43. Lue H, Kapurniotu A, Fingerle-Rowson G, et al. Rapid and transient activation of the ERK MAPK signaling pathway by macrophage migration inhibitory factor (MIF) and dependence on JAB1/CSN5 and Src kinase activity. Cell Signal. 2006;18:688-703.

44. Stumptner-Cuvelette P, Benaroch P. Multiple roles of the invariant chain in MHC class II function. Biochim Biophys Acta. 2002;1542:1-13.

45. Maubach G, Lim MC, Kumar S, Zhuo L. Expression and upregulation of cathepsin $\mathrm{S}$ and other early molecules required for antigen presentation in activated hepatic stellate cells upon IFN-gamma treatment. Biochim Biophys Acta. 2007;1773:219-231.

46. Momburg F, Koch N, Möller P, Moldenhauer G, Butcher GW, Hämmerling GJ. Differential expression of Ia and Ia-associated invariant chain in mouse tissues after in vivo treatment with IFN-gamma. J Immunol. 1986;136:940-948.

47. Becker-Herman S, Arie G, Medvedovsky H, Kerem A, Shachar I. CD74 is a member of the regulated intramembrane proteolysis-processed protein family. Mol Biol Cell. 2005;11:5061-5069.

48. Bernhagen J, Krohn R, Lue H, et al. MIF is a noncognate ligand of CXC chemokine receptors in inflammatory and atherogenic cell recruitment. Nat Med. 2007;13:587-596. 
49. Leng L, Metz CN, Fang Y, et al. MIF signal transduction initiated by binding to CD74. J Exp Med. 2003;197:1467-1476.

50. Shi X, Leng L, Wang T, et al. CD44 is the signaling component of the macrophage migration inhibitory factor-CD74 receptor complex. Immunity. 2006;25:595-606.

51. Gore Y, Starlets D, Maharshak N, et al. Macrophage migration inhibitory factor induces B cell survival by activation of a CD74-CD44 receptor complex. J Biol Chem. 2008;283:2784-2792.

52. Mitchell RA, Metz CN, Peng T, Bucala R. Sustained mitogen-activated protein kinase (MAPK) and cytoplasmic phospholipase A2 activation by macrophage migration inhibitory factor (MIF). Regulatory role in cell proliferation and glucocorticoid action. J Biol Chem. 1999;274: 18100-18106.

53. Javeed A, Zhao Y, Zhao Y. Macrophage-migration inhibitory factor: role in inflammatory diseases and graft rejection. Inflamm Res. 2008;57:45-50.

54. Lan HY. Role of macrophage migration inhibition factor in kidney disease. Nephron Exp Nephrol. 2008;109:e79-e83.

55. Kobayashi S, Nishihira J, Watanabe S, Todo S. Prevention of lethal acute hepatic failure by antimacrophage migration inhibitory factor antibody in mice treated with Bacille Calmette-Guerin and lipopolysaccharide. Hepatology. 1999;29:1752-1759.

56. Adelman N, Cohen S, Yoshida T. Strain variations in murine MIF production. J Immunol. 1978;121:209-212.

57. de Jong YP, Abadia-Molina AC, Satoskar AR, et al. Development of chronic colitis is dependent on the cytokine MIF. Nat Immunol. 2001;2:1061-1066. Erratum in: Sahli MA [corrected to Alsahli M]. Nat Immunol. 2002;3:407.

58. Cao WG, Morin M, Sengers V, et al. Tumour necrosis factor-alpha up-regulates macrophage migration inhibitory factor expression in endometrial stromal cells via the nuclear transcription factor NF-kappaB. Hum Reprod. 2006;21:421-428.

59. Calandra T, Bernhagen J, Mitchell RA, Bucala R. The macrophage is an important and previously unrecognized source of macrophage migration inhibitory factor. $J$ Exp Med. 1994;179:1895-1902.

60. Swant JD, Rendon BE, Symons M, Mitchell RA. Rho GTPase-dependent signaling is required for macrophage migration inhibitory factor-mediated expression of cyclin D1. J Biol Chem. 2005;280:23066-23072.

61. Ohkawara T, Nishihira J, Takeda H, Asaka M, Sugiyama T. Pathophysiological roles of macrophage migration inhibitory factor in gastrointestinal, hepatic, and pancreatic disorders. J Gastroenterol. 2005;40:117-122.

62. Zhang HY, Nanji AA, Luk JM, et al. Macrophage migration inhibitory factor expression correlates with inflammatory changes in human chronic hepatitis B infection. Liver Int. 2005;25:571-579.

63. Zetterman RK, Luisada-Opper A, Leevy CM. Alcoholic hepatitis. Cellmediated immunological response to alcoholic hyalin. Gastroenterol. 1976;70:382-384.

64. Kumagi T, Akbar F, Horiike N, Onji M. Increased serum levels of macrophage migration inhibitory factor in alcoholic liver diseases and their expression in liver tissues. Clin Biochem. 2001;34:189-193. Erratum in: Clin Biochem. 2001;34:517.

65. Hori Y, Sato S, Yamate J, et al. Immunohistochemical study of macrophage migration inhibitory factor in rat liver fibrosis induced by thioacetamide. Eur J Histochem. 2003;47:317-324.

66. Nakajima H, Takagi H, Horiguchi N, et al. Lack of macrophage migration inhibitory factor protects mice against concanavalin A-induced liver injury. Liver Int. 2006;26:346-351.

67. Iwaki T, Sugimura M, Nishihira J, Matsuura T, Kobayashi T, Kanayama N. Recombinant adenovirus vector bearing antisense macrophage migration inhibitory factor cDNA prevents acute lipopolysaccharide-induced liver failure in mice. Lab Invest. 2003;83:561-570.

68. Bozza M, Satoskar AR, Lin G, et al. Targeted disruption of migration inhibitory factor gene reveals its critical role in sepsis. $J$ Exp Med. 1999;189:341-346.

69. Bourdi M, Reilly TP, Elkahloun AG, George JW, Pohl LR. Macrophage migration inhibitory factor in drug-induced liver injury: a role in susceptibility and stress responsiveness. Biochem Biophys Res Commun. 2002;294:225-230.
70. Dvorak HF, Dvorak AM, Churchill WH. Immunologic rejection of diethylnitrosamine-induced hepatomas in strain 2 guinea pigs: participation of basophilic leukocytes and macrophage aggregates. J Exp Med. 1973;137:751-775.

71. Akbar SM, Abe M, Murakami H, et al. Macrophage migration inhibitory factor in hepatocellular carcinoma and liver cirrhosis; relevance to pathogenesis. Cancer Lett. 2001;171:125-132.

72. Beswick EJ, Das S, Pinchuk IV, et al. Helicobacter pylori-induced IL-8 production by gastric epithelial cells up-regulates CD74 expression. J Immunol. 2005;175:171-176.

73. Beswick EJ, Pinchuk IV, Minch K, et al. The Helicobacter pylori urease B subunit binds to CD74 on gastric epithelial cells and induces NF-kappaB activation and interleukin-8 production. Infect Immun. 2006;74:1148-1155.

74. Iizuka N, Oka M, Yamada-Okabe H, et al. Oligonucleotide microarray for prediction of early intrahepatic recurrence of hepatocellular carcinoma after curative resection. Lancet. 2003;361:923-929.

75. Iizuka N, Hamamoto Y, Oka M. Predicting individual outcomes in hepatocellular carcinoma. Lancet. 2004;364:1837-1839.

76. Matoba K, Iizuka N, Gondo T, et al. Tumor HLA-DR expression linked to early intrahepatic recurrence of hepatocellular carcinoma. Int $J$ Cancer. 2005;115:231-240.

77. Iizuka N, Hamamoto Y, Oka M. Prediction of cancer outcome with microarrays. Lancet. 2005;365:1683-1685.

78. Liu YH, Lin CY, Lin WC, Tang SW, Lai MK, Lin JY. Up-regulation of vascular endothelial growth factor-D expression in clear cell renal cell carcinoma by CD74: a critical role in cancer cell tumorigenesis. J Immunol. 2008;181:6584-6594.

79. Ito K, Yamaoka Y, Yoffe B, Graham DY. Disturbance of apoptosis and DNA synthesis by Helicobacter pylori infection of hepatocytes. Dig Dis Sci. 2008;53:2532-2540.

80. Ito K, Yamaoka Y, Ota H, El-Zimaity H, Graham DY. Adherence, internalization, and persistence of Helicobacter pylori in hepatocytes. Dig Dis Sci. 2008;53:2541-2549.

81. Lu XP, Koch KS, Lew DJ, et al. Induction of cyclin mRNA and histone H1-kinase during liver regeneration. J Biol Chem. 1992;267: 2841-2844.

82. Xia JT, Li W, Liu YJ, et al. Correlations of expressions of macrophage migration inhibitor factor and cyclin D1 with tumor size and metastasis of hepatocellular carcinoma. Zhonghua Gan Zang Bing Za Zhi. 2007; 15:918-921.

83. Ren Y, Tsui HT, Poon RT, et al. Macrophage migration inhibitory factor: roles in regulating tumor cell migration and expression of angiogenic factors in hepatocellular carcinoma. Int J Cancer. 2003;107:22-29.

84. Hira E, Ono T, Dhar DK, et al. Overexpression of macrophage migration inhibitory factor induces angiogenesis and deteriorates prognosis after radical resection for hepatocellular carcinoma. Cancer. 2005;103:588-598.

85. Xia JT, Li W, Wu ZF, Zhao J, Wang H, Li YY. Decreased macrophage migration inhibitor factor expression up-regulates p27 in hepatocellular carcinoma. Zhonghua Gan Zang Bing Za Zhi. 2009;17:102-106.

86. LiY, Lu C, Xing G, Zhu Y, He F. Macrophage migration inhibitory factor directly interacts with hepatopoietin and regulates the proliferation of hepatoma cell. Exp Cell Res. 2004;300:379-387.

87. Zhang S, Lin R, Zhou Z, et al. Macrophage migration inhibitory factor interacts with $\mathrm{HBx}$ and inhibits its apoptotic activity. Biochem Biophys Res Commun. 2006;342:671-679.

88. Gando S, Nishihira J, Kobayashi S, Morimoto Y, Matsushita M, Kemmotsu O. Systemic macrophage migration inhibitory factor release following hepatic resection. Surg Today. 2001;31:605-609.

89. Hsieh HC, Chen YT, Li JM, et al. Protein profilings in mouse liver regeneration after partial hepatectomy using iTRAQ technology. J Proteome Res. 2009;8:1004-1013.

90. Abbas AK, Lichtman AH, Pillai S. Cellular and Molecular Immunology. 2010; updated Edition 6; Saunders Elsevier, Philadelphia, p. 1-566.

91. Painter CA, Cruz A, López GE, Stern LJ, Zavala-Ruiz Z. Model for the peptide-free conformation of class II MHC proteins. PLoS One. 2008;3: e2403, 1-10. 
92. Paroli M, Carloni G, Franco A, et al. Human hepatoma cells expressing $\mathrm{MHC}$ antigens display accessory cell function: dependence on LFA-1/ICAM-1 interaction. Immunology. 1994;82:215-221.

93. Herkel J, Jagemann B, Wiegard C, et al. MHC class II-expressing hepatocytes function as antigen-presenting cells and activate specific CD4 T lymphocytes. Hepatology. 2003;37:1079-1085.

94. Kaminski NE, Jordan SD, Page D, Kim BS, Holsapple MP. Suppression of humoral immune responses by dialkylnitrosamines: structure-activity relationships. Fundam Appl Toxicol. 1989;12:321-332.

95. Akimoto M, Yoshikawa M, Ebara M, et al. Relationship between therapeutic efficacy of arterial infusion chemotherapy and expression of P-glycoprotein and p53 protein in advanced hepatocellular carcinoma. World J Gastroenterol. 2006;12:868-873.
96. Daniele B, De Vivo R, Perrone F, et al. Phase I clinical trial of liposomal daunorubicin in hepatocellular carcinoma complicating liver cirrhosis. Anticancer Res. 2000;20:1249-1251.

97. Bokemeyer C, Kynast B, Harstrick A, et al. No synergistic activity of epirubicin and interferon-alpha $2 \mathrm{~b}$ in the treatment of hepatocellular carcinoma. Cancer Chemother Pharmacol. 1995;35:334-348.

98. Sharkey RM, Goldenberg DM. Use of antibodies and immunoconjugates for the therapy of more accessible cancers. Adv Drug Deliv Rev. 2008;60:1407-1420.

99. Griffiths GL, Mattes MJ, Stein R, et al. Cure of SCID mice bearing human B-lymphoma xenografts by an anti-CD74 antibody-anthracycline drug conjugate. Clin Cancer Res. 2003;9:6567-6571.

\section{Publish your work in this journal}

Hepatic Medicine: Evidence and Research is an international, peerreviewed, open access journal covering all aspects of adult and pediatric hepatology in the clinic and laboratory including the following topics: Pathology, pathophysiology of hepatic disease; Investigation and treatment of hepatic disease; Pharmacology of drugs used for

\section{Dovepress}

the treatment of hepatic disease. Issues of patient safety and quality of care will also be considered. The manuscript management system is completely online and includes a very quick and fair peer-review system, which is all easy to use. Visit http://www.dovepress.com/ testimonials.php to read real quotes from published authors.

Submit your manuscript here: http://www.dovepress.com/hepatic-medicine-evidence-and-research-journal 